\title{
Penerimaan Pluralitas Agama sebagai Syarat Kemungkinan Etika Politik
}

\author{
Haryatmoko
}

\begin{abstract}
Religion constitutes the place of peace, the life meaning, and it contains the optimistic goal of human, but (often in reality) it relates to violence phenomenon. The apology is usually declared that religion is actually right values, but the religious people justify their interests in the name of religion. The problem is can religion separate from the followers? So, socializing the ethical values and the acceptance of plurality do not only cognitive aspect, but also habitus meaning. Hence, to develop tolerance attitude, it is urgent to motivate, to educate children since childhood to have habit, involment experience and to communicate with different religion followers, for example paying attention to poor and marginalized people. This together living is the best way to build the possibility of political ethics.
\end{abstract}

Kata kunci: pluralitas, etika , politik, dan agama

A gama sering tampil dalam dua wajah yang saling bertentangan. Dari satu sisi, agama merupakan tempat di mana orang menemukan kedamaian, kedalaman hidup, dan harapan yang kukuh. Di dalam agama, banyak orang dan kelompok menimba kekuatan dan mendapatkan topangan berhadapan dengan penderitaan, penindasan atau rejim totaliter. Dari sisi lain, agama sering dikaitkan dengan fenomena kekerasan, lebih-lebih di Indonesia akhirakhir ini. Pembelaan biasa mengatakan bahwa agama mengajarkan perdamaian, menentang kekerasan, namun manusia menyalahgunakan untuk kepentingan pribadi atau kelompok. Bisakah memisahkan agama dari praktik pemeluknya?

Agama baru menjadi kongkrit sejauh dihayati oleh pemeluknya. Kalau agama menganjurkan pemeluknya untuk menghor- mati dan menghargai sesama manusia, kenyataan sering berbicara lain. Kita sendiri menyaksikan dan sejarah mencatat betapa besar andil agama dalam membakar kebencian dan meniupkan kecurigaan, membangkitkan salah pengertian dan mengundang konflik, meskipun hal itu dibantah oleh banyak pengamat, ia justru menudingnya kesenjangan ekonomi, pertarungan kekuasaan politik, atau kecemburuan sosial. Tetapi masalahnya mengapa agama yang dikatakan bukan pemicu utama konflik justru memberi jaminan dukungan bagi pihak yang bersengketa. Agama sering, bukannya mengelakkan konflik, tetapi malahan memberikan landasan ideologis dan pembenaran simbolis. Pembenaran ini bukan hanya berfungsi meringankan atau memberi alibi tanggungjawab pribadi, tetapi semakin meneguhkan tekad, mempertajam permusuhan dan memistiskan motif pertentangan menjadi perjuangan membela 
iman dan kebenaran, singkat kata demi Tuhan sendiri.

Dengan pemistisan motif tersebut, konflik berubah bentuk menjadi perjuangan yang mempertaruhkan keberadaan manusia. Setiap kompromi akan dianggap sebagai kelemahan atau pengkhianatan. Motif konflik menjadi irasional. Irasionalitas ini tercermin dalam pencampuradukan kepentingan pribadi/kelompok dengan kehendak Tuhan. Agama tidak bisa mengelak dari tanggungjawabnya karena pencampuradukkan itu adalah tanda tiadanya unsur kritis, tidak berfungsinya rambu-rambu pengarah pemahaman atau penafsiran. Kehendak Tuhan mau ditangkap secara langsung dalam ketelanjangan kemampuan manusia. Klaim bahwa agama selalu mengajarkan yang baik memang benar, tetapi apakah para pemuka agama menyadari antara ajaran (pengetahuan) dan tindakan itu masih ada jarak, dan adanya jarak ini sering tidak disadari sehingga seakan-akan bila sudah diajarkan dianggap sudah dilaksanakan. Untuk menjadi tindakan masih butuh jembatan. Keyakinan dan ajaran tidak otomatis menjadi sistem tindakan.

Agama yang kongkrit adalah yang dihayati oleh pemeluknya dengan sistem ajaran, norma moral, institusi, ritus, simbol, para pemukanya. Konflik antar agama terutama antara Islam dan Kristen baik di Lombok, Ambon, Poso dan di kota-kota lain di Indonesia pada dasamya tidak lepas dari kebencian, tidak bisa menerima yang berbeda. Apapun yang dikatakan para pengamat politik dan agama bahwa ada rekayasa konflik, kebencian antara penganut itu memang sungguh ada dan dirasakan. Provokasi tidak akan berhasil kalau kebencian tidak ada. Sedikit provokasi saja sudah akan mudah membakar perilaku agresif atau kekerasan terhadap pemeluk agama lain. Memang masalah kesenjangan merupakan salah satu pemicu, namun yang menjadi kunci pada dasamya ialah tidak bisa menerima yang berbeda. Kehadiran pihak yang berbeda agama mengancam diri saya.

\section{Pluralitas Agama sebagai Syarat Kemungkinan Etika}

Penerimaan pluralitas agama tidak dapat dipisahkan dari penerimaan kebebasan beragama. Masalahnya, banyak pemeluk agama berpikir dengan menggunakan logika biner "agama saya benar, jadi agama lain salah". Bagaimana pemeluk suatu agama bisa menerima, menghargai agama lain dan sekaligus menghayati sebagai otentik kebenaran agamanya? Pertanyaan ini berasal dari keprihatinan bagaimana agar agama menjadi lebih manusiawi. Manusia perlu menghadapi perbedaan agama secara bijaksana agar bisa hidup bersama dalam suasana damai dan produktif. Secara lebih tajam lagi mau ditanyakan apa motivasi yang menggerakkan seseorang manjadi Muslim, Kristen, Hindu atau Budha. Apakah seseorang akan menjadi ateis atau agnostik atau pemeluk suatu agama lain bila ia dibesarkan di lingkungan sosial atau budaya yang berbeda?

Tentu saja, semua pemeluk agama ditandai oleh tradisi, warisan dan latar belakangnya. Namun mereka tidak hanya tunduk pada pengaruh tersebut. Keyakinan mereka tidak melulu dari lingkungan atau pengaruh dari luar, tetapi sungguh didasarkan pada landasan rasionalitas yang berasal dari suatu kedalaman diri. Landasan rasionalitas semacam ini mengandaikan bahwa setiap agama memiliki kekhasannya. Keyakinan akan kekhasannya semakin memperteguh identitasnya sehingga kehadiran agama lain tidak menjadi 
ancaman bagi keberadaan dirinya. Kehadiran agama lain justru semakin menampilkan kekhasannya. Kekhasan suatu agama bukan sama sekali masalah. superioritas. Jangan mencampuradukkan masalah kebenaran dengan argumen superioritas. Unik atau khas, yang berarti hanya satu-satunya dalam jenis itu, tidak identik dengan lebih hebat.

Kekhasan mirip dengan apa yang dalam konsep Levinas sebagai penampakan wajah dalam arti kehadirannya ditandai dengan penolakan terhadap semua upaya untuk mendefinisikan atau mewadahinya. Tidak bisa memaksakan kategori-kategori diri untuk memasukkan yang lain. Maka dalam resistensinya terhadap semua bentuk dominasi, kehadirannya menjadi nyata. Keberadaan yang lain atau yang berbeda tidak perlu dibandingkan dengan diri dan tidak tergantung pada kualitas yang membedakan dengan diri saya. Dengan demikian hubungan dengan yang lain tidak membawa kekerasan asalkan yang lain diterima sebagai penampakan wajah yang menyapa diri. Perjumpaan dengan yang lain akan membuahkan perdamaian dan menumbuhkan struktur kehidupan yang positif, yaitu hubungan etika [L'épiphanie du visage est éthique (Levinas, 1971:2180)]. Oleh karena itu kekhasan mengandaikan penampakan wajah di mana penerimaan pluralitas merupakan syarat yang sangat menentukan.

Penerimaan pluralitas agama-agama seharusnya dipahami dalam perspektif positif, dalam arti pluralitas merupakan cara menampakkan lebih baik kesempurnaan Tuhan, tanpa harus jatuh di dalam bahaya relativisme. Kekhasan suatu agama akan semakin tampak melalui proses dialog dengan agama-agama lain. Dialog merupakan keterbukaan terhadap yang lain. Dialog akan membantu menolong memahami secara lebih baik kekhasan setiap agama dan memberi motivasi untuk mencari dan mengenali Tuhan lebih dari sekedar konseptualisasi formal dari agama masing-masing. Dengan demikian, perbedaan akan diterima sebagai sarana untuk mengungkap kesempumaan Tuhan. "Tuhan begitu kaya dan sangat tak terbatas sehingga tradisi agama tertentu, yang dalam arti tertentu juga terbatas, tidak akan bisa menimba habis kesempurnaan dan kepenuhan Tuhan" (E.Schillebeeckx, 1992: 225). Pernyataan ini menjadi landasan dialog yang secara serius menghormati agama lain di dalam kekhasan dan kekayaan nilainilainya. Namun sekaligus mencegah suatu agama untuk menyatakan diri sebagai yang memiliki monopoli kebenaran. Apakah lalu tidak terjerat pada relativisme?

Bila konsep "relativisme" dipahami dalam arti penerimaan terhadap kontingensi, tanpa mereduksi kekhasan kebenaran suatu agama, kontingensi adalah pembenaran terhadap kondisi sejarawi manusia. Menerima kontingensi berarti membenarkan bahwa kondisi manusia bersifat sejarawi, yang dengan demikian tidak bisa dikaitkan dengan masalah absolutime dan relativisme. Melaluj situasi sejarawi manusia ini, Tuhan mewahyukan diri. Kebenaran yang absolut ini menjadi mungkin dipahami oleh manusia karena Yang Absolut ditangkap dengan kategori-kategori manusia. Tuhan tidak menganggap kekhasan sejarah ini sebagai absolut. Jika Tuhan tidak menganggapnya sebagai absolut, a posteriori Tuhan juga tidak akan memutlakkan suatu agama, tetapi agama dalam arti sebagai lembaga sosio-sejarawi. Jadi pewahyuan Tuhan adalah absolut, tapi kemampuan manusia untuk menangkap pewahyuan tersebut terbatas.

Perbedaan agama mengajak untuk menerima keterbatasan manusia di dalam 
menangkap misteri Tuhan, misteri yang lain dan mengundang untuk menunda hasrat untuk mendominasi yang lain. Dengan demikian pernyataan Levinas menjadi relevan: "Hubungan tidak menetralisir yang lain, tetapi memelihara otentisitas yang lain. Yang lain sebagai yang samasekali lain tidak merupakan obyek yang menjadi milik kita atau cair bersama saya menjadi kita. Sebaliknya, yang lain menarik diri ke dalam misterinya" (Levinaş, 1982:59). Jadi dari perspektif ini, perbedaan antar agama tidak bisa dipecahkan dalam bentuk pernyataan seakan-akan mereka saling melengkapi. Kesalingan yang berakar pada kelemahan merupakan bentuk pengobyekan. Perbedaan-perbedaan teologi yang tidak bisa dipertemukan memang ada, tidak perlu disangkal. Dialog bukan berarti menganeksasi yang lain atau menolak yang lain, tidak pula untuk memaksakan sudut pandangnya. Dialog tidak bisa direduksi hanya menjadi masalah ketidakjelasan semantik atau masalah perbedaan perspektif. Kalau anggapannya demikian, berarti seakan-akan bisa dipecahkan dengan memberi kiarifikasi di dalam penggunaan istilah atau konsep. Orang harus memperbaharui pemahaman bahwa yang berbeda atau yang lain bukan merupakan bagian saya, tidak mirip dengan saya, tetapi sungguh suatu kesadaran yang ada di luar saya, tetapi saya sangat menghormatinya.

Di dalam perjumpaan yang tulus, yang lain menyentuh saya dan "menyandera saya" dalam rumusan Levinas. Menyandera saya karena saya ditatapkan pada ketidakmungkinan untuk menolak rintihan permohonan pihak lain. Tanggung jawab mendahului kebebasan. Subyektivitas saya diusik bahkan sebelum mampu mengambil keputusan. Kehadiran yang lain membuat saya bertanggung jawab atas nasibnya, khususnya penderitaan dan kesengsara- annya. Pernahkan anda dikejutkan oleh adanya kecelakaan lalu meninggalkan semua yang sudah anda rencanakan untuk menolong yang terluka dengan membawanya ke rumah sakit? Bahkan sebelum saya sempat memutuskan, yang terluka menuntut saya melakukan tindakan yang bertanggung jawab. Perjumpaan dengan yang lain merupakan momen etika. Dalam konteks dialog antar agama, etika ini tidak bisa lepas dari politik. Etika politik harus dipahami sebagaj politik yang bertanggung jawab terhadap pihak lain, terutama semua pihak lain sebagai bentuk pluralitas yang membentuk suatu komunitas. Maka fokus utama etika politik adalah masalah keadilan. Keadilan menuntut agama-agama mengorganisir hubungan yang etis dalam rangka membantu yang miskin dan tersingkir. Jadi etika selalu politik.

\section{Pluralitas Agama dan Etika Politik}

Kalau berbicara mengenai agama dan etika politik, orang tidak hanya berhenti pada masalah perilaku politikus atau moral orang perorangan. Etika dalam konteks ini berhubungan juga dengan praktik institusi sosial, hukum, komunitas dan strukturstruktur sosial, politik dan ekonomi. Lalu akan menjadi kelihatan bahwa etika memiliki tiga dimensinya yaitu tujuan, sarana dan aksi politik itu sendiri.

Jadi tiga dimensi etika politik itu adalah pertama, tujuan politik; kedua, menyangkut masalah pilihan sarana; ketiga, berhadapan dengan aksi politik. Yang terakhir ini langsung terkait dengan perilaku politikus.

Dimensi tujuan terumuskan dalam upaya mencapai kesejahteraan masyarakat dan hidup damai yang didasarkan pada kebebasan dan keadilan. Keprihatinan utama ialah upaya penerapan kebijakan umum (policy) dalam manajemen publik. Dalam negara demokratis, pemerintah 
Penerimaan Pluralitas Agama sebagai Syarat Kemungkinan...; Haryatmoko

KESEJAHTERAAN UMUM dan KEDAMAIAN

[dalam kebebasan dan keadilan]

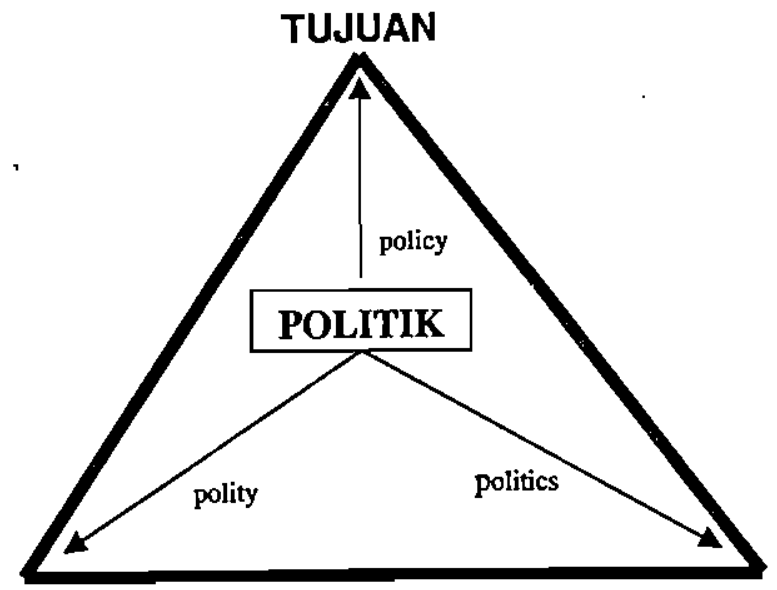

\section{SARANA}

Tatanan Politik (Hukum dan Institusi)

- Prinsip solidaritas dan subsidiaritas

- Keadilan prosedural

- Penerimaan pluralitas

Struktur sosial direkayasa secara politik

menurut prinsip keadilan

Kekuatan Politik ditata

- sesuai dengan prinsip timbal-balik

\section{AKSI}

Rasionalitas Politik dalam:

- Orientasi situasi

- Persepsi kepentingan

- Manajemen konflik

- Disposisi kekuasaan

- Menghindari kekerasan

Keutamaan dalam Rasionalitas Politik

- Kebijaksanaan

- Keadilan

- Keberanian

- Penguasaan diri

[Bdk.Bernhard Sutor, Politische Ethik, Ferdinand Schoningh, Paderborn, 1991, hal. 86]

mempunyai komitmen terhadap penyelenggaraan negara dan bertanggungjawab atas komitmen tersebut: kesejahteraan masyarakat dan hidup damai. Menghadapi masalah-masalah negara, kebijakan umum pemerintah harus terumus jelas dalam hal prioritas, program, metode dan pendasaran filosofisnya. Lalu menjadi transparan apa yang harus dipertanggungjawabkan. Atas dasar kebijakan umum ini agama sebagai institusi, wakil rakyat dan kelompok-kelompok masyarakat bisa membuat evaluasi pelaksanaan, kinerja pemerintah dan menuntut pertanggungjawaban. Kejelasan tujuan yang terumus dalam kebijakan publik akan menunjukkan ketajaman visi seorang pemimpin dan kepedulian suatu partai politik terhadap aspirasi masyarakat. Dimensi moralnya terletak pada kemampuan menentukan arah yang jelas kebijakan umum dan akuntabilitasnya. 
Dimensi etika politik kedua ialah sarana yang memungkinkan pencapaian tujuan (polity). Dimensi ini meliputi sistem dan prinsip-prinsip dasar pengorganisasian praktik penyelenggaraan negara dan yang mendasari institusi-institusi sosial. Hal yang terakhir ini ikut menentukan pengaturan perilaku masyarakat dalam menghadapi masalah-masalah dasar. Pola-pola tersebut mengandung imperatif normatif yang disertai sangsi. Dimensi sarana (polity) ini mengandung dua pola normatif: pertama, tatanan politik (hukum dan institusi) harus mengikuti prinsip solidaritas dan subsidiaritas, penerimaan pluralitas; struktur sosial ditata secara politik menurut prinsip keadilan. Maka asas kesamaan dan masalah siapa diuntungkan atau siapa dirugikan oleh hukum atau institusi tertentu relevan untuk dibahas; kedua, kekuatankekuatan politik ditata sesuai dengan prinsip timbal-balik. Gagasan Habermas "masingmasing pihak sepakat mengkoordinasikan tindakan mereka untuk mencapai tujuan masing-masing" (1981, Vol.., hal. 117) relevan dengan pola normatif kedua ini. Dimensi moral pada tingkat sarana ini terletak pada peran etika dalam menguji dan mengritisi legitimitas keputusan-keputusan, institusiinstitusi dan praktek-praktek politik.

Bila tekanan diarahkan pada pendekatan struktural ada implikasi etis, yaitu kesulitan dalam menentukan tanggungjawab pelaku karena otonomisasi tindakan.. Tindakan lepas dari maksud awal pelaku dan bergerak dengan dinamikanya sendiri. Pelaku mengelak bertanggungjawab atas tindakannya karena rentang waktu dan jarak pelimpahan tugas. Meskipun para jendral dalam kasus Trisakti lepas dari tuntutan hukum, secara moral mereka bisa dipersalahkan in causa (penyebab dalam konteks waktu). Bila hukum positif belum memiliki pasal yang merumuskan jenis kejahatan ini, hakim bisa mengacu ke prinsip epikeia (rasa keadilan), dengan argumen kesalahan in causa itu. Masalahnya, sulit menentukan batas tanggungjawab. Hukum penal yang menekankan individualisasi kesalahan mempersulit penentuan batas tanggungjawab itu. Pada tingkat sarana, dimensi moral dalam menghadapi struktur terletak pada persetujuan atau penolakan terhadap tatanan sosial, ekonomi dan politik hidup bersama.

Dimensi ketiga etika politik adalah aksi politik (politics). Dalam dimensi etika ketiga inj pelaku memegang peran sebagai yang menentukan rasionalitas politik. Rasionalitas politik terdiri dari rasionalitas tindakan dan keutamaan (kualitas moral pelaku). Tindakan politik disebut rasional bila pelaku mempunyai orientasi situasi dan paham permasalahan. Ini mengandaikan kemampuan mempersepsi kepentingan-kepentingan yang dipertaruhkan berdasarkan peta kekuatan politik yang ada. Disposisi kekuasaan ini membantu untuk memperhitungkan kemampuan dan dampak aksi politiknya. Menghindari kekerasan menjadi imperatif moral (ungkapan hormat terhadap martabat manusia), maka penguasaan manajemen konflik adalah syarat aksi politik yang etis. Oleh karena itu aksi mengandaikan keutamaan: penguasaan diri dan keberanian memutuskan serta menghadapi resikonya. Fair dan adil dalam hubungan dengan yang lain. Pada dimensi aksi ini, etika identik dengan tindakan yang rasional dan bermakna. Politik mempunyai makna karena memperhitungkan reaksi yang lain: harapan, protes, kritik, persetujuan, penolakan. Makna etis akan semakin dalam bila tindakan pelaku didasari oleh belarasa dan keberpihakan kepada yang lemah atau korban. Dalam hal ini, agama berperan di dalam pembiasaan dan pembentukan tindakan yang bertanggung jawab, penuh 
bela rasa dan berpihak kepada yang lemah. Doktrin dan praktik agama ikut mengondisikan perilaku atau tindakan para penganutnya.

Kalau agama mau menyumbang konstruksi budaya politik, membangun etika politik bisa dalam dua kemungkinan: aspek normatif dan penalaran politik yang benar. Etika politik menunjuk aspek normatif budaya politik santun. Pertama, etika politik mengajak untuk berpikir secara kritis dalam arti menempatkan pada posisi orang lain. Menerima yang berbeda agama atau mereka yang dalam posisi lemah menuntut sikap terbuka. Memperhitungkan orang lain, "penampakan wajah" ('épiphanie du visage menurut Levinas) dan mempunyai empati mengandung dimensi moral yang dalam. Tiadanya pemikiran yang menempatkan diri pada posisi orang lain sudah merupakan bentuk kejahatan atau awal dehumanisasi.

Kedua, etika politik membantu untuk memberi penjelasan isi normatif yang ditunjukkan oleh sejarah, fakta ekonomi, sosial atau budaya. Negara kesejahteraan merupakan semacam koreksi sosialisme terhadap liberalisme ekonomi. Nilai etisnya ialah menggugat sistem pasar bebas karena yang menjadi korban, yang lemah biasanya diabaikan karena moral Darwinisme (survival for the fittest). Maka negara dituntut membantu pemenuhan kebutuhan dasar bagi yang kalah itu. Dalam rangka pemberdayaan yang lemah itu, agama sebagai institusi sosial sangat diharapkan perannya dan juga dalam kerjasamanya dengan agama-agama lain. Ketiga, etika politik menguji dan mengritik legitimitas keputusan politik, institusi dan praktik politik. Dasar pemikirannya ialah semua tindakan dan praktik kekuasaan membutuhkan legitimasi. Peran profetis agama dalam konteks ini ialah mengritisi ketidakadilan dan praktikpraktik penyelenggaraan negara yang menyimpang dari etika politik. Dan juga mendorong agar negara memperhatikan yang miskin, yang terpinggirkan dan korban. Posisj agama (bukan bagian dari political society, tapi civil society) diandaikan tidak langsung ambil bagian dalam upaya mempertahankan kekuasaan atau memperoleh kekuasaan politik, tapi perjuangan demi tegaknya keadilan. Dengan demikian agama tidak dicurigai mempunyai kepentingan langsung. Bila demikian, kritiknya akan memiliki kredibilitas tinggi.

Aspek budaya politik santun lain ialah penalaran politik yang benar. Penalaran politik yang benar menyangkut tiga hal: isi, prosedur dan kontekstualisasi. Mengenai isinya, filsafat politik menjelaskan konsepkonsep, prinsip-prinsip serta cara penalaran khas praktek institusi-institusi dan ideologiideologi politik. Lalu menetapkan cara pandang tertentu agar bisa membuat penilaian. Maka suatu penilaian mengandaikan adanya ideal. Ini yang menuntut pemahaman sejarah filsafat politik. Agama juga bisa menawarkan gagasannya, tetapi harus terbuka untuk diperdebatkan dan dikritisi. Sedangkan prosedurnya menyangkut apa yang mau dikomunikasikan. Filsafat politik mau mengomunikasikan penalaran dan prosedur yang digunakan dalam menetapkan norma-norma yang bisa diterima sebanyak mungkin anggota masyarakat. Hal ini nampak jelas dalam teori keadilan J.Rawls dan teori tindakan komunikatif J.Habermas. Akhimya, tuntutan kontekstualisasi dimaksudkan untuk memahami kebaharuan yang berkembang dewasa ini seperti transformasi negara, demokrasi, kejahatan struktural, fenomena korupsi, civil society, kekerasan politik serta kecenderungan primordialisme

Menjadi semakin jelas, bahwa dari uraian tentang tiga dimensi etika politik tersebut, perilaku orang perorangan hanya 
merupakan salah satu dimensi etika yang terkait dengan masalah kehendak baik. Tetapi di dalam pewujudannya, kehendak baik perlu ditopang oleh institusi-institusi yang adil. Dengan membangun institusiinstitusi yang lebih adil ini, mau dibangun jembatan antara kehendak baik dan pewujudannya. Kehendak baik berfungsi untuk mempertajam makna tanggung jawab, sedangkan institusi (aturan, hukum, kebiasaan, lembaga sosial) berperan untuk mengorganisir tanggung jawab atau menciptakan kondisi bagi tindakan yang bertanggung jawab. Namun interaksi yang sebaliknya juga benar, yaitu bahwa kebiasaan yang baik akan mampu menciptakan struktur-struktur sosial yang kondusif bagi terciptanya tindakan yang bertanggung jawab.

Dalam upaya mempertajam makna tanggung jawab itu, agama diharapkan berperan besar. Dimensi individual dari etika sangat menonjol karena fokusnya membahas masalah kualitas moral pelaku. Jadi masalah keutamaan atau kebajikan pelaku menjadi sangat menentukan dalam menghasilkan tindakan yang bertanggung jawab karena keutamaan merupakan faktor stabilisasi tindakan yang berasal dari dalam diri pelaku (Bemhard Sutor, 1991:65). Hanya perlu disadari bahwa pernyataan yang mengatakan "bila orangnya jujur, semua akan beres" ternyata masih mengandung kelemahan. Cara pemahaman seperti ini mengabaikan dinamika tindakan sosial yang mengandaikan adanya determinasi strukturstruktur sosial. Oleh karena itu perlu memperhitungkan faktor stabilisasi tindakan yang berasal dari luar diri pelaku atau yang disebut struktur-struktur sosial tindakan. Maka diperlukan institusi (hukum, tatanan sosial, kebiasaan, tradisi) untuk menjamin stabilitas tindakan dari luar diri pelaku (Bernhard Sutor, 1991:65). Hukum, aturan, tradisi dan institusi sosial lainnya itu berperan untuk mengorganisir tanggung jawab agar kehendak baik tidak hanya kandas menjadi janji kosong atau hanya berhenti pada pernyataan yang tidak pernah bisa diwujudkan. Maka hukum juga memberi sangsi bila orang atai kelompok mangkir terhadap janji atau mengelak dari tanggung jawab. Dalam perspektif ini, bisa menjadi jelas mengapa dualisme kehidupan mudah terjadi: di satu pihak, orang tekun dan taat beribadah; di lain pihak, korupsi dan kekerasan tetap merajalela. Ada keterputusan antara perilaku individual dan perilaku sosial. Ada jurang antara kehendak baik dan realitas pewujudannya, antara norma dan realitas (das Sollen/das Sein). Ada yang tidak berfungsi dalam interaksi antara pelaku dan struktur-struktur sosial, antara sarana dan aksi.

Interaksi antara dua dimensi etika (sarana dan aksi) sangat menentukan hasil tindakan, atau dengan kata lain, interaksi antara pelaku dan struktur-struktur sosial menjadi kunci dalam pembentukan tindakan yang bertanggung jawab. Bentuk interaksi tersebut bisa dijelaskan melalui sudut pandang beberapa teori sosial sehingga memberi gambaran secara lebih rinci peran agama. Pemikiran Michel Crozier, Anthony. Giddens, Michel Foucoult, Pierre Bourdieu dan Paul Ricoeur dengan jeli dan kritis membantu dalam menganalisa peran agama di dalam dinamika tindakan sosial.

\section{Mencari Dimensi Etika dalam Dialektika Aktor dan Sistem}

Penjelasan yang sekarang ini sudah menjadi klasik adalah dari Michel Crozier. Dalam bukunya yang ditulis bersama Erhard Friedberg, L'acteur et le système (1977), Michel Crozier menjelaskan dialektika antara pelaku dan sistem: struktur-struktur sosial hanya bisa diciptakan, dilanggengkan, dan 
diubah oleh pelaku-pelaku sosial; sebaliknya, pelaku sosial kendati dikatakan bebas, dikondisikan oleh struktur-struktur tersebut. Dimensi dualitas pelaku dan struktur masih sangat kuat. Pendekatan ini menekankan analisis hubungan-hubungan kekuasaan dan organisasi-organisasi. Para pelaku sosial yang sekaligus rasional dan rasionalitasnya terbatas, mempunyai marka kebebasan yang menjadi dasar kekuasaan mereka. Keberhasilan strateginya sangat ditentukan oleh strategi yang digunakan lawannya. Pernyataan tentang strategi tindakan ini dapat diilustrasikan di dalam kisah dilema dua narapidana.

Ada dua narapidana yang dituduh melakukan kejahatan yang sama. Polisi tidakmempunyai bukti untuk menjebloskan mereka ke dalam penjara. Maka ditahan di ruang yang terpisah dengan harapan akan mendapatkan pengakuan salah satu dasi keduanya. Bila narapidana yang satu menuduh yang lain maka yang dituduh akan dihukum 10 tahun penjara, dan yang lain bebas. Tentu saja pemecahan yang dianggap paling rasional ialah memperjuangkan kepentingan masing-masing, yaițu menuduh yang lain telah melakukan kejahatan tersebut supaya dirinya dibebaskan. Bila keduanya berpikir rasional, akibatnya justru keduanya celaka. Mereka berdua dijebloskan ke penjara. Hanya masih ada satu jalan keluar yang merupakan momen moral, yaitu bila masing-masing narapidana itu percaya, bahwa temannya tidak akan mencelakai dirinya. Dengan jalan ini masing-masing bungkam, tidak mau menuduh yang lain sehingga polisi terpaksa membebaskan mereka.

Percaya kepada yang lain atau kelompok lain merupakan unsur dasar etika sosial. Di Indonesia, suasana kecurigaan yang dalam antar kelompok baik etnis, dan terutama agama membutuhkan terobosan- terobosan untuk mengatasinya. Agamaagama diharapkan mengambil inisiatif untuk mengadakan dialog agar runtuh prasangkaprasangka negatif terhadap agama lain. Lalu akan ditumbuhkan rasa tanggung jawab terhadap nasib orang lain atau mereka yang berbeda dengan saya. Dengan cara ini, tindakan strategis yang memperlakukan pihak lain hanya menjadi sarana diarahkan menjadi tindakan komunikatif (J. Habermas, 1987). Pihak lain sekaligus diperlakukan sebagai mitra, saksi, dan tempat obyektivasi. Keprihatinan utama adalah mencari kesepakatan agar bisa bertindak bersama untuk perdamaian dan keadilan. Keadilan menuntut agama-agama untuk berjuang bagi mereka yang miskin dan yang menjadi korban. Jangan sampai perbedaan agama berubah menjadi konflik dan semakin menambah korban-korban kekerasan dan ketidakadilan. Maka setiap pihak diharapkan mengupayakan untuk menunda kepentingan masing-masing. Mengapa tuntutan ini diarahkan ke agama-agama?

Agama di Indonesia masih sangat kuat mempengaruhi tindakan sosial dan warna politik. Pertama, dengan membuat percaya bahwa orang berada dalam kontak dengan makna yang terdalam dari keberadaannya, agama memperkuat motivasi tindakan (Paul Ricoeur, 1986); kedua, agama menunjukkan pemeluknya ke tujuan akhir atau terdalam sehingga akan memberi suatu legitimitas tindakan dan mendasari sikap kritis terhadap tatanan yang ada. Kedua fungsi agama ini merupakan unsur-unsur yang mendasari tiga peran agama yang sangat rentan terhadap kekerasan, yaitu peran agama sebagaj ideologi, sebagai faktor penentu identitas, dan sebagai legitimasi etis hubungan sosial.

Pertama, peran agama sebagai ideologi. Agama menjadi perekat suatu masyarakat karena memberi kerangka penafsiran dalam pemaknaan hubungan-hubungan sosial. 
Sejauh mana suatu tatanan sosial dianggap sebagai representasi religius yang dikehendaki Tuhan. Masalah tatanan sosial ini menjadi peka sehingga perbedaan pendapat yang menjurus ke konflik akan sangat mudah dipicu terutama yang berkaiatan dengan masalah kekuasaan. Pemaknaan atau penafsiran cenderung menyembunyikan kepentingan-kepentingan pribadj atau kelompok. Penyembunyian kepentingan ini terkait dengan peran ideologis agama, dalam arti sebagai faktor integrasi dan pembenaran dominasi. Apa yang ditafsirkan dan mendapat pembenaran dari agama adalah hubungan kekuasaan. Setiap tindakan dan setiap kekuasaan selalu mencari legitimasi. Kekuasaan menuntut lebih dari keyakinan yang kita miliki. Untuk mengisi kekurangannya, agama berperan sebagai sistem pembenaran dominasi.

Kedua, agama dalam perannya sebagaj faktor identitas dapat didefinisikan sebagai kepemilikan pada kelompok sosial tertentu. Kepemilikan ini memberi stabilitas sosial, status, pandangan hidup, cara berpikir dan etos tertentu. Pertentangan pribadi atau etnis bisa menyulut dan berubah menjadi konflik antar agama. Ada dua hal yang sangat kuat dihayati dalam konteks ini, yaitu pertama, agama sebagai faktor perekat sosial dan, kedua, agama menjadi struktur simbolis dari ingatan kolektif pemeluknya. Ingatan kolektif terhadap peristiwa perwahyuan yang menjadi raison d'être kelompok sosiai tersebut. Oleh karena itu identitas agama tidak bisa dilepaskan dari masalah stabilitas dan status sosial, serta landasan keberadaan pemeluknya.

Ketiga, agama menjadi legitimasi etis hubungan sosial. Berbeda dengan agama sebagai kerangka penafsiran, peran agama yang ketiga ini bukan sakralisasi hubungan sosial, namun suatu tatanan sosial mendapat dukungan dari agama. Identifikasi sistem sosial, politik atau ekonomi tertentu dengan nilai-nilai agama tertentu akan memancing penolakan oleh agama lain. Klaim bahwa nilai-nilai HAM berasal dari Barat, yang sering diidentikkan dengan Kristianisme, bisa memancing reaksi penolakan dari bangsa-bangsa Timur dan dari Islam. Penolakan semacam ini menjadi rentan terhadap kekerasan karena semakin menjauhkan kesepakatan bersama dalam penentuan kriteria obyektif tindakan. Penolakan bukan pertama-tama keberatan terhadap substansi HAM itu, tapi lebih karena klaim bahwa nilai-nilainya berasal dari agama atau budaya yang berbeda dari agama atau budaya saya. Maka legitimasi etis hubungan sosial akan mudah menyulut konflik.

Bila pemahaman dan penghayatan agama yang dominan mengarah ke ketiga peran tersebut, maka tidak mengherankan bahwa yang berkembang justru fanatisme. Hannah Arendt, filsuf politik murid Heidegger, mengingatkan: "Kita tergoda untuk mengubah dan menyalahgunakan agama menjadi ideologi, dan menodai usaha yang telah kita perjuangkan melawan totalitarisme dengan suatu fanatisme. Padahal fanatisme adalah musuh besar kebebasan". Fanatisme cenderung menimbulkan konflik dan kekerasan. Namun, dari pemikiran Crozier tentang interaksi pelaku dan struktur sosial tidak bisa dijelaskan bidang-bidang apa yang lebih berperan di dalam interaksi tersebut. Dan tidak bisa dijelaskan proses strukturisasi itu sendiri. Maka, menjadi menarik untuk memahami bentuk-bentuk yang dominan di dalam interaksi sosial. Struktur sosial mana yang mempengaruhi dialektika pelaku dan struktur-struktur sosial sehingga mampu menganalisis ke arah mana dinamika sosial menuju: konflik, kekerasan atau kedamaian. 


\section{Agama, Kekerasan dan Strukturasi Sosial}

Dalam kerangka menjawab masalah tersebut di atas, teori strukturasi Anthony Giddens menjadi relevan. Menurut Giddens, interaksi yang berulang dan terpola dalam jangka waktu tertentu dan dalam ruang tertentu akan menghasilkan struktur. Interaksi itu dilakukan oleh pelaku-pelaku dan dibentuk di dalam perilaku subyek pelaku (1993:128). Srukturasi sebagai reproduksi berbagai praksis, mengacu kepada proses dinamis yang membentuk struktur (ibid., 128). Giddens melihat adanya dualitas struktur dalam arti bahwa struktur sosial dibentuk oleh pelaku namun sekaligus menjadi sarana pembentukan itu sendiri (ibid., 129). Dengan kata lain, struktur sosial merupakan tujuan atau hasil dari interaksi yang berulang dan terpola, namun sekaligus menjadi sarana yang mengondisikan tindakan. Skema interaksi dualitas struktur itu dapat digambarkan sebagai berikut: pemaknaan akan apa yang dilakukan dan dikatakan tidak bisa lepas dari kerangka penafsiran tersebut. Kerangka penafsiran ini tidak lepas dari tatanan pengetahuan kognitif yang menjadi sruktur pemaknaan suatu komunitas. Demikian pula sebaliknya, struktur pemaknaan suatu komunitas membentuk tatanan pengetahuan kognitif. Sedangkan hubungan kekuasaan sangat ditentukan oleh fasilitas yang dimiliki. Akumulasi kepemilikan fasilitas ini semakin meningkatkan kemampuan di dalam mempengaruhi perilaku pihak-pihak lain atau kemampuan dominasinya. Akhirnya, semua tindakan, termasuk kekuasaan, selalu membutuhkan dasar pembenaran. Kerangka ini masuk di dalam interaksi moralitas. Dasar pembenaran tindakan atau kekuasaan itu didapat dari norma (hukum, tradisi, agama, aturan, kebiasaan) atau tatanan yang sah. Ketiga interaksi (komunikasi, kekuasaan dan moralitas) dan struktur yang dibentuk (pemaknaan,

\begin{tabular}{|c|c|c|c|c|}
\hline INTERAKSI & Komunikasi & \multicolumn{2}{|c|}{ Kekuasaan } & Moralitas \\
\hline MODALITAS & $\begin{array}{l}\text { Kerangka } \\
\text { Penafsiran }\end{array}$ & $\begin{array}{l}\text { Fasilitas: } \\
\text {-Politik } \\
\text {-Ekonomi } \\
\text {-Ideologi. }\end{array}$ & $\begin{array}{l}\text {-Budaya } \\
\text {-Militer }\end{array}$ & $\begin{array}{l}\text { Norma: } \\
\text {-Hukum -Agama } \\
\text {-Aturan, Kebiasaan } \\
\text {-Tradisi }\end{array}$ \\
\hline STRUKTUR & Pemaknaan & Dom & inasi & Legitimasi \\
\hline
\end{tabular}

[Anthony Giddens, New Rules of Sociological Method. A Positive Critique of Interpretative Sociologies, Polity Press, Cambridge, 1994, 129]. Skema ini ditambah dengan rincian pada kolom fasilitas dan norma.

Ada tiga bentuk interaksi sosial yang dominan di dalam masyarakat yaitu komunikasi, kekuasaan dan moralitas. Makna Komunikasi di dalam interaksi ditentukan oleh kerangka penafsiran. Maka dominasi, legitimasi) merupakan kesatuan integral, sedangkan pemisahan itu hanya pada tingkat analitis (A.Giddens, 1994:129130). 
Dualitas struktur dari Giddens tersebut sangat membantu menempatkan peran agama di dạlam dinamika sosial. Di dalam interaksi komunikasi, peran agama sangat menentukan karena memberi kerangka penafsiran hubungan-hubungan sosial. Agama menjadi perekat suatu masyarakat karena memberi kerangka penafsiran di dalam pemaknaan hubungan-hubungan sosial. Penafsiran ini menentukan kriteria sejauh mana suatu tatanan sosial dianggap sebagai representasi religius yang dikehendaki Tuhan. Masalah tatanan sosial ini menjadi peka sehingga perbedaan pendapat yang menjurus ke konflik akan sangat mudah dipicu terutama berkaitan dengan masalah kekuasaan. Apalagi kalau ada kelompok yang mempunyai pemahaman ekslusif dalam pemaknaan hubungan-hubungan sosial tersebut. Dengan demikian interaksi komunikasi ini tidak bisa dipisahkan dari interaksi kekuasaan dan moralitas karena menyangkut legitimasi kekuasaan juga. $\mathrm{Hal}$ ini terkait dengan kepentingan kelompok atau pribadi.

Pemaknaan atau penafsiran cenderung menyembunyikan kepentingan pribadi atau kelompok. Penyembunyian kepentingan ini terkait dengan peran ideologis agama, dalam arti sebagai faktor integrasi dan pembenaran dominasi. Apa yang ditafsirkan dan mendapat pembenaran dari agama adalah hubungan kekuasaan karena setiap - tindakan dan setiap kekuasaan selalu mencari legitimasi. Kekuasaan biasanya menuntut lebih dari keyakinan yang kita miliki. Untuk mengisi kekurangannya, agama berperan sebagai sistem pembenaran dominasi. Sistem pembenaran dominasi ini berakar pada identitas kelompok mayoritas. Maka agama bisa berperan sebagai fasilitas interaksi kekuasaan sejauh agama tersebut dipeluk oleh penduduk mayoritas. Dominasi akan semakin kuat bila mendapat dukungan atau fasilitas dari agama. Dengan demikian agama berperan sebagai faktor identitas.

Faktor identitas ini bisa didefinisikan sebagai bentuk kepemilikan pada kelompok sosial tertentu. Kepemilikan ini memberi stabilitas sosial, status, pandangan hidup, cara berpikir dan etos tertentu. Jabatan tertentu hanya mungkin diampu oleh orang yang beragama tertentu. Kepemilikan pada agama tertentu akan memberi fasilitas mendapatkan pekerjaan, sekolah atau kemudahan-kemudahan lain dalam hal ekonomi atau sosial-budaya. Identitas agama ini lalu menjadi bagian dari martabat, harga diri dan kebanggaan. Dasar penghayatan semacam itu berasal dari dua fungsi agama. Pertama, agama sebagai faktor perekat sosial dan, kedua, agama menjadi struktur simbolis ingatan kolektif pemeluknya. Ingatan kolektif terhadap peristiwa perwahyuan atau akta pendiriannya itu menjadi raison d'être kelompok sosial tersebut. Jadj kalau identitas agama disentuh atau tidak dihormati akan segera memicu konflik karena, disadari atau tidak, mengancam status sosial, stabilitas hidup, dan raison d'être pemeluknya.

Hal yang baru atau gagasan baru tidak akan dengan mudah diadopsi. Bila gagasan baru itu mengancam kohesi sosial atau mempertanyakan sistem yang ada, berarti yang terancam juga adalah kepentingan. Bisa dalam arti stabilitas sosial, status, cara berpikir atau juga kepentingan dalam arti nikmat sosial yang melekat pada kepemilikan identitas sosial dan jabatan. Maka menghadapicara penafsiran baru atau pembaharuan di dalam doktrin teologi, reaksi pertama biasanya adalah penolakan. Orthodoksi merupakan bentuk kelambanan dan sikap tidak kritis ideologi yang juga 
melekat pada setiap agama. Tidak mengherankan bila dalam skema dualitas struktur Giddens di atas, hubungan horisontal antara pemaknaan-dominasilegitimasi cenderung ditentukan oleh dominasi, artinya dalam kenyataan dominasi menentukan pemaknaan dan legitimasi. Artinya, pertama, penafsiran yang dianggap paling benar ditentukan oleh kelompok yang dominan pada masa itu, atau dengan kata lain kerangka penafsiran yang berlaku adalah yang dipakai oleh pihak yang sedang dalam kekuasaan; kedua, model legitimasi juga sangat bergantung pada siapa yang sedang berkuasa. Akhirnya, dalam hal agama juga berlaku adanya hubungan pengetahuan-kekuasaan dan kebenaran. Dari sini muncul pandangan kritis terhadap agama, namun membantu menyadari adanya mekanisme kekerasan yang tidak bisa dilihat hanya sekedar dengan sosiologi agama.

Lembaga produksi kekuasaanpengetahuan yang dahsyat adalah agama, kata Michel Foucault. Agama tidak bisa dipisahkan dari mekanisme dan teknik kekuasaan normatif dan disipliner. Agama mengatur individu dan masyarakat melalui teknik penyeragaman baik perilaku, bahasa, pakaian, maupun ritus. Dengan teknik itu akan dihasilkan identitas, yang akan memudahkan untuk mendapatkan kepatuhan dari pemeluknya. Teknik penyeragaman juga berfungsi untuk menafikkan mereka yang bukan pengikut. Dari sini diskriminasi dengan mudah akan beroperasi. Teknik kekuasaan agama ini sangat rentan terhadap kekerasan.

Obyek dan sasaran kekuasaan disipliner agama paling utama adalah seksualitas. Cara berpakaian, wacana sampai ritus diarahkan untuk mengontrol perilaku agar hanya pasangan suami-isteri sah yang mempunyai akses. Penyeragaman cara berpakaian membuahkan identitas yang jelas dan memudahkan pengawasan, artinya pengawasan sekaligus diintemalisir menjadi motivasi diri. Dan halusnya, bukan atas nama pengawasan seragam itu dianjurkan, tetapi untuk kebaikan pemakai dan sesamanya. Seragam memberi status sosial yang jelas dengan semua privilesenya.

Seragam mengarahkan atau lebih tepat membatasi gerak dan perilaku pemakainya. Penyeragaman ini tidak hanya mengenai pakaian, tetapi juga wacana, bahkan sampai perbendaharaan kata yang dipakai. Akhimya yang dicari adalah kepatuhan. Bila sudah patuh semua menjadi mungkin. Cara ini semakin mempertajam perbedaan dan memudahkan tindak diskriminasi, dengan mudah dibedakan yang masuk kelompok dan yang di luar. Hanya saja karena diskriminasi seperti ini, kehadiran yang lain tidak menumbuhkan belarasa, tetapi menjadi ancaman sehingga justru mendorong ke kebencian. Lalu perjumpaan dengan pihak lain bukan menjadi momen etika, tetapi konflik dan kekerasan. Bagaimana menciptakan suasana agar perjumpaan dengan yang lain menjadi momen etika?

\section{Dialog dalam Analogi Permainan}

Dialog antar agama pada tingkat teologi cenderung formal dan serius. Suasana seperti itu bisa kontra-produktif, terlebih kalau sampai tergelincir di dalam apologi. Maka perlu mengambil jarak dari suasana tegang itu. Analogi permainan merupakan pengambilan jarak yang positif (Paul Ricoeur, 1986). Permainan merupakan bentuk pengambilan jarak terhadap kehidupan yang terlalu formal dan serius. Di dalam permainan, seseorang dibebaskan dari ketakutan terhadap norma-norma sosial dan sangsi-sangsinya, dari keseriusan hidup 
dan tekanan hirarki sosial. Permainan membantu kita menyingkap kemungkinankemungkinan baru yang terpenjara oleh pemikiran-pemikiran yang terlalu serius. Tindakan-tindakan kreatif tidak akan berkembang bila visi kehidupan dibatasi hanya pada pertimbangan-pertimbangan moral. Moral cenderung memaksakan pembatasan atau larangan pada manuver imajinasi. Padahal, kebebasan merupakan tanah yang subur bagi kreativitas.

Melalui permainan, fenomena dasariah mekar, yaitu proses kelahiran kreativitas. Pertama-tama di dalam imajinasi dan bukan di dalam kehendak kreativitas-kreativitas baru bermunculan karena kemampuan ditangkap oleh kemungkinan-kemungkinan baru mendahului kemampuan untuk memilih atau memutuskan. Imajinasi merupakan dimensi pada diri orang yang menjawab teks sebagai daya poetis. Dalam konteks analagogi permainan ini, dialog antar agama berarti menciptakan kesempatan perjumpaan-perjumpaan informal seperti olahraga bersama, lomba teater, apresiasi musik, camping, bentuk-bentuk festival bersama. Kegiatan-kegiatan semacam itu akan mengurangi suasana tegang dalam hubungan antar agama dan memungkinkan perjumpaan pribadi atau perjumpaanperjumpaan lain tanpa pretensi apa-apa. Perjumpaan semacam ini merupakan bentuk dialog yang tulus tanpa diarahkan oleh kepentingan tertentu. Analogi permainan akan membantu mengurangi prasangka-prasangka negatif terhadap agama lain. Di dalam perjumpaan yang tulus seperti itu, yang lain menyentuh eksistensi saya dan "menyandera saya", dalam rumusan Levinas. Kehadiran yang lain membuat saya bertanggungjawab atas nasibnya, terutama penderitaan dan kesengsaraannya. Inilah yang disebut momen etika. Masih dalam perspektif
Levinas ini, Paul Knitter dengan jeli merumuskan "Yang lain, yang menderita menjadj perantara atau saluran kepercayaan dan penuh-pengertian antara dunia agama yang berbeda" (1995). Jadi etika bukan pertama-tama teori atau rumusan norma-norma, tetapi pengalaman, atau pengalaman perjumpaan dengan penderitaan yang lain.

Bila etika pada dasarnya adalah masalah pengalaman, penyampaian nilainilai akan lebih efektif bila juga melalui pengalaman. Penyampaian nilai-nilai ini, dan juga penerimaan pluralitas tidak pertamatama dipahami sebagai pemahaman kognitif, tetapi dalam arti habitus menurut Pierre Bourdieu. Nilai-nilai dan norma-norma seharusnya menjadi disposisi yang tertanam di dalam kepribadian seseorang sebagai ketrampilan dalam tindakan praktis yang berkembang berkat suatu lingkungan tertentu, dan pada gilirannya ikut menentukan terbentuknya struktur sosial tertentu (Pierre Bourdieu, 1994:16-17). Dengan demikian, sejak masih kanak-kanak dibiasakan untuk bergaul dengan mereka yang berbeda agama agar paradigma kehidupan tidak hanya dibatasi pada mereka yang seagama. Selain itu untuk mengembangkan toleransi dengan pemeluk agama lain, menumbuhkan belarasa terhadap yang miskin dan yang tersingkir, pengalaman hidup bersama dengan mereka adalah cara yang terbaik.

Pengalaman menunjukkan, bahwa perjumpaan dengan korban-korban kekerasan, korban intoleransi atau konflik agama akan membantu menumbuhkan belarasa seseorang terhadap pemeluk agama Jain, dan mempertajam pemikiran kritis terhadap fanatisme, pandangan agama yang sempit. Ketrampilan seperti ini akan merobohkan semua bentuk prasangka negatif terhadap agama-agama lain dan 
Penerimaan Pluralitas Agama sebagai Syarat Kemungkinan...; Haryatmoko

akan mempertajam rasa tanggung jawab terhadap yang lain. Familiaritas dengan pihak lain akan membantu lebih terampil di dalam menangani perbedaan. Hal ini sudah merupakan bentuk ketrampilan di daiam manajemen konflik.

\section{Daftar Pustaka}

Arendt, Hannah, 1983, Condition de /homme moderne, traduit de l'anglais par Georges Fradier, Paris:CalmannLevy.

Aristote, 1992, Ethique à Nicomaque, Paris: Librairie Générale Frạnçaise.

Baron, Marcia W.,1997, Three Methods of Ethics, Oxford:Blackwell.

Baumgarth, William P. (ed:), 1988, Saint Thomas Aquinas On Law, Morality, and Politics, Cambridge: Hackett.

Bertrand, Michel (éd.),1996, Violences et Pouvoirs Pollitiques, Toulouse: Presses Univ. du Mirail.

Bourdieu, Pierre,1994, Raisons pratiques. Surla théorie de l'action, Paris: Seuil.

Bourdieu, Pierre,2000, Les structures sociales de l'économie, Paris: Seuil.

Cohen, Herman, 1990, La religion dans les limites de la philosophie, Paris: CERF.

Critshley, Simon,1992, The Ethics or Deconstruction. Derrida and Levinas, Oxford: Blackwell.

Foucault, Michel, 1969, L'archéologie du savoir, Paris: Gallimard.

Foucauit, Michel, 1975, Surveiller et punir, Paris: Gallimard.
Foucault, Michel, 1976, Histoire de la sexualité $l$. La volonté de savoir, Paris: Gallimard.

Giddens, Anthony, 1993, New Rules of Sociological Method, Cambridge: Polity Press.

Giddens, Anthony, 1984, The Constitution of Society, Cambridge: Polity Press.

Gordon, Neve, 1999, Ethics as Reciprocity. An analysis of Levinas's Reading of Buber, in: International Studies in Philosophy.

Habermas, Jürgen,1987, Théorie de l'agir communicationnel, Tome I, diterjemahkan dari bahasa Jerman oleh Jean Marc Ferry, Paris, Fayard.

Halbwächs, Maurice, 1997, La mémoire collective, Paris : Albin Michel.

Haryatmoko, J.,2003, Etika Politik dan Kekuasaan, Jakarta :Kompas Buku.

Jayme, Virginia L., Emmanuel Levinas' Philosophy of Responsible Subjectivity, in:Philippiniana Sacra, Vol.XXV1, no. 77 (1991), pp.227-262.

Jeanrond, Werner G., and Rike Jennifer L.1991, Radical Pluralism and Truth, New York: Crossroad.

Knitter, Paul,1995, One Earth Many Religions. Multifaith Dialogue and Global Responsibility, Orbis Books.

Levinas, Enmanuel,1971, Totalité et infini. Essai sur l'extériorité. La Haye: M. Nijhoff.

Levinas, Emmanuel,1982, Ethique et Infini, , Paris: Fayard. 
Topik: Agama dan Teologi Populis Transformatif

Macintyre, Alasdair, 1988, Whose Justice? Which Rationality?, London, Duckworth.

Merquior, José-Gilherme, 1986, Foucault ou le nihilisme de la chaire, Paris, PUF.

Michaud, Yves, 1978, Violence et Politique, Paris : Gallimard.

Newberry, Paul A., 1999, Theories of Ethics, London :Mayfield.

Pinto, Louis, 1998, Pieme Bourdieuet la théorie dumonde social, Paris : Albin Michel.

Quilab, Oliver D., (November 1995), Welcoming The Stranger: Levinas'Ethical Philosophy of Responsibility, in: Diwa 20.

Ricoeur, Paul, 1986, Du texte à l'action. Essais d'herméneutique II, Paris:Esprit-Seuil.

Ricoeur, Paul, 1991, Soi-même comme un autre, Paris : Seuil,

Schillebeeckx, Edward, 1992, L'histoire des hommes, récit de Dieu, traduit du néerlandai par Hélène CornelisGevaert, Paris:CERF.

Sterba, James P. (ed.), 2001, Social and Political Philosophy, London: Routledge.

Sutor, Bernhard, 1991, Politische Ethik, Paderborn, Ferdinand Schöningh.

Thayse, Jean Luc, 1998, Fécondité et évasion chez Levinas, in: Revue Philosophique de Louvain.

Tugendhat, Ernst, 1998,Conferences sur l'éthique, Paris, PUF.

Westphal, Merold, Levinas and The Immediacy of The Face, in: Faith and Philosophy, Vol.10, no. 4 October 1993, pp.486-501

Wimmer, Reiner, 1980, Universalisierung in der Ethik, Frankfurt am Main, Suhrkamp. 